DOI: https://doi.org/10.47405/mjssh.v5i10.524

\begin{tabular}{|c|c|}
\hline 4 & Malaysian Journal of Social Sciences and Humanities (MJSSH) \\
\hline $\begin{array}{l}\text { Malaysian Journal of } \\
\text { Social sciences and }\end{array}$ & Volume 5, Issue 10, October 2020 \\
\hline (MJ-SSH) & e-ISSN : 2504-8562 \\
\hline & $\begin{array}{l}\text { Journal home page: } \\
\text { www.msocialsciences.com }\end{array}$ \\
\hline
\end{tabular}

\title{
The Voice of the Black Female Other: A Post-Colonial Feminist Perspective in J. M. Coetzee's Age of Iron
}

\author{
Suadah Jasim Salih ${ }^{1,2}$, Lajiman Janoory ${ }^{1}$ \\ 1Department of English Language and Literature, Faculty of Languages and Communication, \\ Universiti Pendidikan Sultan Idris (UPSI), Malaysia \\ 2Directorate of Cultural Exchange, General Directorate of Cultural Relations, \\ Ministry of education, Republic of Iraq
}

Correspondence: Suadah Jasim Salih (suadahsalih75@gmail.com)

\begin{abstract}
As a beacon in a storm, John Maxwell Coetzee has established himself through his intellectual contribution to the post-colonial feminism literature in general and South African slavery epoch in particular. Accordingly, this study has been devoted to critically reflect how Coetzee confined his pen to support the oppressed black South Africans against injustice, oppression and deprivation. Moreover, the paper reveals the South African inextricable components and haw the writer has deeply perceived both apartheid and post-apartheid history by his naked eyes. Coetzee's Age of Iron reveals his unique ability to aptly penetrate his readers based on contradiction where pessimism is shifted to optimism and, therefore, the readers' mindset is directly shifted from atrocity to love. The study then delves deeply to show how Coetzee provides a solution to bring two parted races, black and white South Africans, together through the role of women characters in his fiction based on both gender and racial schism. Specifically, this study critically scrutinizes Coetzee's Age of Iron. The study applies the postcolonial feminism theory using discursive strategy based on sociological and anthropological analyses to reveal how colonization destroyed South Africans' cultures resulting in a crisis of human segregation which is depicted through white women characters in the novel. By drawing the postcolonial black women's treatment by the colonisers and the forms of resisting their hegemony, the findings of this study are expected to significantly contribute to the researchers whose concern is on black women in Coetzee's fiction.
\end{abstract}

Keywords: apartheid, black women, Coetzee, feminism, post-colonial literature, South Africa

\section{Introduction}

From 1948 to early 1990s, white South Africans ruled the country through a system known as 'apartheid', which means 'separateness' in the Afrikaner language. In other words, apartheid is the rule of 'separate development' involving racial profiling, political and economic discrimination against nonwhite groups that inhabited South Africa until 1990. The system allowed the minority white population of South Africa to dominate the country's indigenous black population. The blacks were disenfranchised and could not hold certain jobs or live in certain areas of their country. Hence, apartheid deprived blacks many basic human rights and forced them to live in ghettoes (rundown section of a city) and go to separate schools. Based on that, the whites have total control over the 
blacks where apartheid evolved laws that allowed the ruling white minority in South Africa to relegate, exploit and terrify the natives (Wade, 2016).

Even though apartheid came to an end in December 22, 1993, post-independent South Africa was by no means peaceful and there are many problems. Violence increased considerably in the major towns. Incidents of robbery increased and many commercial farmers either emigrated or gave up farming because of violence committed against them on their isolated farmhouses. From 1989 to 1994, the rate of crime increased and young South African women are expected to be raped twice in their lifetime on average and racism still exists in South Africa. In other words, violent crimes have become extensive; vandalism and robbery occur frequently at the countryside. Hence, the power is exchanged, blacks now rule their country. However, Coetzee portrays South Africa during its emergence from centuries of colonialism and settler racism, and reflects on the notion of being in post-apartheid South Africa. As the violence from a history of oppression cannot be suppressed, Coetzee brings racial tensions to the forefront of his literature. James (2020) asserts that "Coetzee's clear sense of resolve here emphasizes for us today Age of Iron's double vision - looking into the private self, looking out, though often intermittently, at immediate atrocity - which is also the culmination of a complicated trajectory in his method through the 1980s (p. 71). After the publication of Coetzee's Age of Iron (1990), the issue of feminism, was emphasized as another phenomenon which had never been critically scrutinized. Therefore, the issue of feminism raises Coetzee's motivation to use women to be chosen as typical narrators (Salih \& Janoory, 2019).

Age of Iron can be defined as is a literary fiction which mainly focuses on the painful influence of Apartheid on the psyche of both the oppressor and the oppressed in South Africa. It is the novel which is directly drawn to reflect the actual status of the historical period in South Africa bearing a vivid depiction of the deterioration and injustice of the Blacks life under the ruling regime. It visualizes the struggling events of Blacks for liberation. It has been argued that Age of Iron marks a shift of emphasis from the perspective the Blacks to the perspective of the Whites under the same ruling system of apartheid (Khalaf, 2019, p. 45).

Delving deeply into Age of Iron, one can find that Coetzee uses the character of Mrs. Curren to scrutinize the intersection between the classical European literary canon and apartheid South Africa. However, it can argue that Age of Iron never provide a direct answer to the question of where the European literary canon fits into the domain of apartheid South Africa. The novel deals with functions as an essential test of the fundamental value of those same human relations regardless of race and color. Throughout the novel, the frequent failures of Mrs. Curren do not suggest that the conventional education which enlightens her mode of caring has no chance in apartheid South Africa, rather, the intervention between the European predominating culture and the South Africans' status of poverty and ignorance need to be re-contextualized. Lucia (2020) argues that "because Mrs. Curren reveres the classics and persists as an unsuccessful but still highly sympathetic character throughout the novel, Coetzee suggests the lasting importance of the classics as an influence on the modern literary canon, a canon which perhaps includes Age of Iron itself" (p. 21).

Coetzee's historical guilt recognition can be beheld as his sympathy with decolonization procedure. Hence, he speaks from the identity perspective of both literature and position which cannot be considered as a typical example of any ordinary Afrikaner whose identity can be acknowledged and rejected. Consequently, Coetzee is found to be living his own way and he is not related to any identity group. This can easily be touched in his autobiographical fiction series where he is found as a person who has an identity loss as depicted in Summertime, expressing his ambition to live the time in which South Africans leave in freedom and peace. In Doubling the point, Attwell recorded Coetzee's position as an African who looks at his nation from his own perspective. During the interviews, Coetzee obviously describes his position stating that:

No Afrikaner would consider me an Afrikaner ... I am one of many people in the country, who have been detached from their ethnic roots, whether these roots were in Dutch South Africa or Indonesia or Britain or Greece or wherever, and have joined the pool of no recognizable ethnos whose language of exchange is 
English... and as the pool has no discernable ethnos, so one day I hope it will have no predominant color as more people of color drift into it. A pool I would hope then, in which differences mash away (Attwell, 1992, pp. 341-342).

This research paper is particularly appropriate in revealing the condition of black women in South African literature through the fictional works of J. M. Coetzee. Throughout South Africa, Black Women had suffered untold hardship that made them angry and become frustrated at having their freedom of movement restricted by the hated official apartheid policies which compelled them to be carrying passes wherever they go. The bravery of some of these black women who risked their life in case of official reprisals including arrest, detention and even assassinations is supposed to be applauded by scholars. These important issues are the target of this research to be critically analysed and highlighted.

\section{Literature Review}

Post-colonialism was extensively used to indicate experiences of the societies that were politically, linguistically, and culturally controlled by previous European colonies. Therefore, post-colonialism concentration focused on societies and cultures affected by colonization. It chronologically described the post-independence period and critics used post-colonialism to signify the different cultural effects of colonization by the end of 1970 s. The processes of subjugation overwhelmed the colonized who became the consequences of the development of European all over the world. Consequently, the imperial process of the term "post-colonial" was meant to include the cultural ground affected from the beginning of colonization to the present day. In their book titled Key Concepts in Postcolonial Studies, Ashcroft et al. (2013) maintained that:

"post-colonialism is now used in wide and diverse ways to include the study and analysis of European territorial conquests, the various institutions of European colonialisms, the discursive operations of empire, the subtleties of subject construction in colonial discourse and the resistance of those subjects, and, most importantly perhaps, the differing response to such incursions and their contemporary colonial legacies in both pre- and post-independence nations and communities" (p. 187).

According to modern literary critics, post-colonial theory of literature and culture strives for a very strong resistance. It assumes that the writers represent the people of their societies by writing back to the centre. This theory has emerged as a part of the decentring propensity of post 1960s and was genuinely assumed in the west. Dennis Walder (1990) particularized that "post-colonial theory is needed because it has a subversive posture towards the canon, in celebrating the neglected or marginalized, bringing with it a particular politics, history and geography" (p. 60). Moreover, postcolonial criticism and post-colonial theory gained their considerable outcome throughout the discouragement of the general privileges when prepared by liberal humanist critics to signify literature. The one-sidedness to judge all literature through a single universal standard had led to lack of respect of social, cultural, regional, and national variances in experience, vision, and knowledge. Additionally, the theory did not merely restrict the situation to literature as it is extended to cover parts for study as film, art, and performance media.

This research attempts to study the selected novels of J. M. Coetzee from the perspective of postcolonial feminist theory, in which it provides insights into Coetzee's art and innovative process. It traces the development of female status within Coetzee's work which is worthy to be investigated. The study also evaluates post-colonial and hierarchal dominance upon women, oppression, resistance, and psychological impact on women as Age of Iron, the considered for investigation in this research paper. The women's physical damage helped them acquire power in order to resist oppression. This resistance arisen due to women being marginalized in the society. They faced depression and suffered from physical and emotional alienation. They developed anxiousness and, as a result, they became selfestranged because they did not grow along their social surroundings. Women eventually experienced 
psychic sickness evidenced from their traumatic silence. In the past, women gradually failed at communicating effectively and suffered from the consequences of post-colonial and hierarchical hegemony. Coetzee's critical works on literary theme were wide-open in reference to South African women and society as a whole. Furthermore, women's enthusiasm and spirit to endure African colonial patriarchy were recognized, and women's resistance to gender inequality in post-colonial South Africa were argued.

This study highlights the subjugation that had been discussed by many prominent and globally acclaimed writers from various African countries, who themselves had experienced the colonial atrocities or had witnessed the unjust system that did not give equal opportunity for all citizens in the same country. The propounded inequalities were based on manifold politics involving race, gender, and colour creed, among others by the imperialists who governed the country and took charge in making policies. The works of post-colonial critics such as, Frantz Fanon (2001), Homi Bhabha (2003), Edward Said (2012) and Gayatri Spivak (2016) had been comprehensively considered in this study. As such, the submission and compliance apparent in J. M. Coetzee' novels were questioned to understand the myriad shades of the voices of the subalterns. If one makes an attempt to understand the depth of muteness in post-colonial terms, Senghor's analysis of the typical qualities of the South African Blacks would be essential:

The African is as it were shut up in his Black skin. He lives in primordial night. He does not begin by distinguishing himself from the object of study, the tree, or stone, the man or anima or social event. He does not keep it at a distance. He does not analyse it. Once he has come under its influence, he takes it like a blind man, still living, into his hands. He does not fix or kill it (Senghor, 1965, pp. 29$30)$.

Hence, the struggles that were common for women, men and children during the colonial period and the various problems the country faced during the struggle for independence constitute the need for conducting this study. However, the researchers are aware of the painful truth that complete truth is not fully available as many black women and men had actually suffered during the colonial period and did not openly speak about their experiences due to deficiency of discursive power. The truth and reconciliation hearings held during apartheid era, for example, did not make it easy for researchers to discover if the whole truth was ever brought to light or would truth still exist with individuals who might not be part of the information available.

Likewise, this study takes gander at how Coetzee utilized the female suffering in creating these books about female heroes defying the prevailing patriarchy. The significance of Coetzee's depictions of female characters was established in most of his work of fiction and one of which Age of Iron. In Coetzee's works women performed various roles inside a colonizing patriarchal world symbolising a reserve of silence and purity in the materiality of its traffic with the noisy discourse of the world where colonization caused a harmful impact on women as well.

\section{Apartheid in Age of Iron}

Age of Iron narrates the plight of the black African community among the entire hateful racism of the rest of their society. As the novel was set in Apartheid Cape Town in the late twentieth century, it obviously visualizes the real context of South Africa. In the novel, Mrs Curren is a first-person narrator depicted in an epistolary style. Reading the novel, one can feel as to be addressed since she uses "you" to address her daughter in her letters. As it is about Mrs Curren's perspective on the world, Coetzee's novel can be understood as a coming-of-age novel. By a strange twist of fate, Mrs. Curren soon finds herself fighting a battle she didn't previously know existed. As her life becomes interwoven with the various people she takes into her home, she then realizes that the black people are in fact seriously subjugated. Though not a supporter of Apartheid, she didn't know before the extent of the hatred which gave birth to the segregation laws. Additionally, she learns about the corrupt nature of the nation's security. The policemen who are supposed to care for people end up deliberately hurting and murdering 
them because they are seeing as "Other". Mrs. Curren awakens to this cruel world which she was not aware of. Her white pride fades as quickly as her health and that makes her realizes life poor and homeless people. She painfully says:

There were not so many of these homeless people in your time. But now they are part of life here. Do they frighten me? On the whole, no. A little begging, a little thieving; dirt, noise, drunkenness; no worse. It is the roaming gangs I fear, the sullen-mouthed boys, rapacious as sharks, on whom the first shade of the prisonhouse is already beginning to close. Children scorning childhood, the time of wonder, the growing-time of the soul. Their souls, their organs of wonder, stunted, petrified. And on the other side of the great divide their white cousins soul-stunted too, spinning themselves tighter and tighter into their sleepy cocoons. Swimming lessons, riding lessons, ballet lessons; cricket on the lawn; lives passed within walled gardens guarded by bulldogs; children of paradise, blond, innocent, shining with angelic light, soft as putti. Their residence the limbo of the unborn, their innocence the innocence of bee-grubs, plump and white, drenched in honey, absorbing sweetness through their soft skins. Slumbrous their souls, bliss-filled, abstracted (pp. 4-5, Age of Iron).

Mrs Curren has been battling breast cancer and later she has discovered that the disease has metastasized and becomes incurable. In this difficult situation, and in the same day she gets her ominous prediction, she finds a homeless man living on her back entrance of her house. What signifies the novel is letter written by Mrs. Curren to her daughter explaining situation and through this letter Coetzee aptly reveals the two aspects of life. The first is the vanity of life which is reflected through the life of Mrs. Curren and her husband. The second is the harmful impact of apartheid and otherness which rely on gender, race and colour segregation in South Africa. As Mrs. Curren seems emotionally remote and alone, she is more open and because of that she has an acquaintance with Vercueil who later becomes the closest person to her. As the play goes on, Mrs. Curren becomes more aware of the suffering and needs of others even though she is not always at ease with what she is observing in her surrounding world including her witness of the brutality of police that makes her acrimonious and causes her to disrespect the entire world. As her health gets worse, she recommends Vercueil what he should do with her body after death:

'For bones. For hair. Sell my teeth too. Unless you think I am worth nothing. It's a pity we don't have one of those carts that children used to wheel the Guy around in. You could wheel me down the Avenue with a letter pinned to my front. Then you could set fire to me. Or you could take me to some more obscure place, the rubbish dump for instance, and dispose of me there' (pp. 118, Age of Iron).

Coetzee has expressively exposed the evils of racism which was allowed free reign during apartheid. Through the character of Mrs Curren, readers embark on an emotional journey of discovery. They are gradually made to see the blatant corruption of apartheid which was designed to oppress the black people. As a result, Mrs. Curren takes up the cause of the oppressed as soon as she realizes what is happening. She is dying of cancer, nonetheless, her efforts are seemingly small but truly that is all she can contribute. In this way, her final days are graceful. Even though, she is dying, physically, in order to live better, however, she is now fully aware and active in order to help bring about a positive change. All of this is communicated to her estranged daughter as a sort of confession. Under this assertion, Mrs Curren, as narrator, discloses to readers as if she knew and loved them personally. Age of Iron compels readers to consider and cope with ideas of racism, death, and loss in a very intimate way.

The main theme of the novel is apartheid and consequently displays of racism are a recurring motif. The reason why white's violence goes unpunished is apartheid. Apartheid was the rule of law that discriminated against black and colored citizens and gave authorities freedom to treat them as less than humans. This intolerance became increasingly violent. The police are openly and increasingly brutal to black citizens, profiling them at the start of the novel and escalating to murder as the novel reaches a 
climax. The fact that Mrs Curren's' daughter is overseas is also due to apartheid. The reason for social unrest politically is also because apartheid as more and more people of all ethnicities protest and show their resistance. The theme of the book is racism but the way in which this racism is systematically both tolerated and encouraged is because of apartheid.

Motherhood was women's primary role, just as witness in Coetzee's Age of Iron where Florence tries albeit in vain to protect her sons at all cost. They had to raise children, care for the home and see to the needs of the family. In African societies women were expected to undertake agricultural tasks as well to help feed the family. Others took in laundry and house help to provide extra income while some entered into the labour market as domestic servants. In settler society too, it was not considered feminine to work outside the home, although some women did so to supplement the family income and help put food on the table.

\section{Oppression and Subjugation of Black Women in Age of Iron}

John Maxwell Coetzee's novels can be read as a reflection on black women subjugation in all its complexity, articulating and commenting upon many of the positions typical of the radical feminism of the seventies. Some feminists classify oppression as a form of rape as an ideal form of sex for the main characters, in some of his works, because it allows especially white men to fantasize that a woman mirrors their wishes. Coetzee takes a dreadful scene of violence and involves readers to view it not from the perspective of analysing the issues of the blacks, in spite of his ability to use narration and juxtaposition skillfully and characteristically, but as a chance to renovate normative approaches to human relationships including rape and justice. In Coetzee's novels readers are always encouraged to rethink and not only rely on the assumptions through which black on white rape is viewed.

In Age of Iron, Coetzee evidently highlights the violence caused by both, the whites and blacks. The blacks are exasperated and the youth throw themselves against the whites with high ideals of participation. Consequently, in his novels, Coetzee deals with oppression through devoting his characters as mostly use passive resistance to defeat the oppression. Their weapon is only silence which they can resort as a mode of disobedience. In her letters, Elizabeth Curren, a white widower expounds on the rising tide of militancy among black youths; overcome, resistant and vindictive, they are a generation whose hearts have swung to press because of the state abuse and treacheries. The novel's title Age of Iron captures the embodiment of the contemporary socio-political milieu in South Africa seeing the final breaths of the dishonorable arrangement of racial segregation called politicallysanctioned racial segregation. Despite its historiographical connotations, it has nothing to do with the archaeological era in history coming after the Bronze Age and set apart by the predominant utilization of iron as an instrument for completing an assortment of undertakings.

This expression refers differently to the iron will be the dark youngster progressives, her little girl's firm purposes not to come back to South Africa till the National Party rules, her persistence both in not persuading her girl to return and her political will and to the iron laws of child rearing material to both Florence and herself. To put it differently, it refers to the epoch of political unrest and anarchy in South Africa set apart by a vicious protection of the dark youth in light of the State's politically sanctioned racial segregation approaches. Thus, Coetzee's Iron Age denotes the prevalent chaotic state of affairs resulting from the rigid and oppressive apartheid laws as well as the rebellious and disillusioned mood of the black insurgents.

In the opening part of the novel, it appears during one of her dialogues with her maid in the sense of insensitivity and hard-heartedness. Florence who justifies the violent actions of her son thus:

These are good children, they are like iron, we are proud of them...Children of iron...Florence herself, too, not unlike iron. The Age of Iron, after which comes the age of bronze. How long, how long before the softer ages return in their cycle, the age of clay, the age of the earth? A Spartan woman is iron-hearted and 
bearing warrior sons for the nation. We are proud of them. We come home either with your shield or on your shield (p. 50 Age of Iron).

The novel offers a dismal, although entirely truthful, a picture of the misery, injustice and other social evils that fuels selfless acts of rebellion. Coetzee seems to say that the mindset of the boys is 'afflicted' and obsessive to a cause greater than their selves hardening them into an iron-like commitment and fighting spirit for justice.

Meanwhile, her housekeeper, Florence informs that in certain areas in South Africa, black teenagers have burned down their schools out of protest against the apartheid regime. She admits that she would not have known about these riots if Florence had not told her: "Of trouble in the schools the radio says nothing, the television says nothing, the newspapers say nothing. In the world, they project all the children of the land are sitting happily at their desks" (p. 39 Age of Iron). It means that the apartheid government tries to keep their citizens ignorant of the entire situation of a flaming civil war by providing them with incorrect information.

\section{Women activism}

To black women demanding for equality and fairness do not necessarily mean a desire to do away with male leadership in the home, society and nation as propagated by European feminists. There are at least two features to consider in understanding the unwillingness of several black women to fully hold the rights discourse of women and make aggression against women an issue of socio-political importance. Firstly, this has to do with the historical perspective of the discourse and how black women joined it. Secondly, black women have different awareness of the pressing needs and priorities in their struggles for basic survival and lager communal emancipation.

In the Age of Iron, Coetzee exposes the dilemma of the black woman through the eyes of a dying old white woman, Mrs. Curren. As mentioned earlier, the text is set in Apartheid Cape Town of South Africa in the late twentieth century. The narrator recounts the difficulty of the black African women within the clear hateful racism of the rest of their community. By a strange twist of fate, Mrs. Curren soon finds herself fighting a cancer battle she didn't earlier know existed. As her life becomes gradually intertwined with the people she accommodates in her home, she begins to understand that the black people are in fact gravely oppressed. Even though not a supporter of Apartheid, she didn't previously know the extent of the hatred which gave birth to the segregation laws. Moreover, she learns about the corrupt nature of the police force. The establishment which is supposed to protect people ends up deliberately harming and murdering them because of their skin color. Mrs. Curren awakens to this cruel world which she never before knew. Her white privilege fades as quickly as her health. Bhagavatidevi et al. (2017) comment that "Age of Iron shows the dreadful apartheid from the matured, intellectual and solemn eyes of Mrs Curren who had only heard about its eeriness, but at closing of the final chapter of her life she has its firsthand experience" (p. 778).

This reluctance has not been a hindrance in the way of women being active in South Africa's struggle against racial oppression. The country celebrates the National Women's Day on August 9. In March, 1956, there was a historic day of women from various racial, ethnic and class backgrounds. The march was a clear display of the power of women to publicly make their voices heard on matters they considered vital to their everyday lives. This event and the more sustained role of women in South Africa's liberation movements were to mark the participation of women in government after apartheid.

Although not necessarily universally approved, the participation of women in government is arguably taken to be balance for the course. Moreover, this is aided by the implementation of quota systems and the country's allegiance to international human rights charter. And yet this rhetoric of women empowerment has done little to radically halt the plague of women harassment in the country. The modern concept of human rights that informs international human rights originated in the context of ethnocentric European endeavours at achieving consensus-based nation building. The ideal was conceived in 17 th century. In this context, rights were understood to be entitlements allocated to 
rational individual human agents - namely, white European males. This individualized European, malecentric concept of human rights is often contrasted with African customary emphasis on collective rights based on ascribed gender roles, such as sex, lineage, age, and individual progeny. The European concept of rights excluded two broad categories of people: white women and all non-Europeans subjected to European colonial domination, including slavery. Whereas white women were considered to be imperfect humans lacking rationality, the basic humanity of all non-Europeans was totally rejected (Sanders, 2006).

Even though a white woman, Mrs. Curren in Age of Iron has trusted that forceful activism, particularly when it incorporates violence and, therefore, it is risky and unsafe. Her all around characterized views are first tested when she witnesses the police ruthlessly strike Bheki and his companion outside her home in an unjustifiable ambush. Even Bheki moves her view that he is "demolishing his future" in the city killing his profitable time till politically sanctioned racial segregation arrives at an end by crossaddressing in this manner "What is more important, that apartheid must be destroyed or that I must go to school?" (p. 65 Age of Iron). She comes to realize that the militant black youth represented by Bheki and his friend ignore her advice. Myklatun (2018) asserts that Mrs. Curren looks at South Africa as a country which "has degenerated into a period of desolation, pain and destruction because of the brutalizing effects of the state's violence. The state's implementations of systematic rule and racial classification has produced the violence of the black opposition" (Myklatun, 2018, p. 28).

Mrs. Curren accepts them reluctantly, but with strong disapproval of their harshness and intolerance. She also tries to convince Bheki and his friend to abandon their allegiance to activism, which the police prey upon. In total contrast to her advice, Bheki's mother, Florence defends their arrogance and stoneheartedness saying "This is not my child, this is the white man's child, and this is the monster made by the white man" (p. 50 Age of Iron). She proudly says "They are not afraid to die" suggesting their readiness to sacrifice for the cause of resistance. She gets affected more and more emotionally and physically as the novel progresses.

The protagonist experiences the police brutality consistently, and when she tries to make things right, she finds that there's nothing that she can do. She starts to realize that she's living in a world in which rules are always being reinvented and nullified. Her quest and genuine sympathy for apartheid victims take her to the hospitals where black children are subjected to neglect, and inhumane treatment, and to townships destroyed by security forces. Such exposure to apartheid in her final days awakens her to the world she had known of and condemned but never seen.

In Age of Iron, Vercueil is a taciturn alcoholic and a homeless black man living in South Africa under the apartheid regime. Being a white woman, Mrs. Curren tries to be ethically responsible toward Vercueil and listen to his story. It can be claimed that the theme of silence and its counterpart, speech, figures prominently in Coetzee's fiction. Louise Racine (2011) states that "postcolonial feminist approaches unpack the cultural, historical, social, and economic factors that intersect to shape different oppressive contexts that affect health and well-being" (p. 18).

\section{Conclusion}

Coetzee's novelistic practice can be described as antihistorical though several of his novels involve obviousness with historical events. For example, Age of Iron reflects the return of Coetzee to realism where he addresses the problem and suggests that a novel is produced based on the process of opposition with historical discourse and not the 'supplementarity.' Head (2009) views in Coetzee's fiction a novel "operates in terms of its own procedures and issues in its conclusions, not one that operates in terms of the procedures of history and eventuates in conclusions that are checkable by history" (p. 24). Additionally, the use of allegory is considered as a distinctive characteristic of Coetzee's novels which persists as a major theme of the postcolonial writing. Since the message encoding makes it more difficult to handle, allegory comes to work as a device to hide ideas. The allegory use, either that devoted for the political aspects or the one that reveals the artistic underpinnings, supports Coetzee to represent the actual status of the South African society. 
Based on the viewpoints discussed above, a significant viewpoint could be mentioned where this study has revealed how Coetzee reflects apartheid as the only rule of law discriminated against colored black and citizens and granted authorities freedom to treat blacks as less than human. Therefore, Coetzee is seen as he is devoting his characters to act within the domain oppression such as seen in the character of Mrs. Curren, in Age of Iron, who adopts the struggle of the oppressed as soon as she realizes what she is dying of cancer in spite of all her efforts to contribute revealing her awareness of the importance of positive change even though she is physically dying. As the mouthpiece of Coetzee, Mrs. Curren is found to be responsible to inspire readers as if she knew and loved them personally so that she comes able to convince them with ideas of racism, death, and loss in a responsive way.

To conclude, the study reveals contradictory interactions between whites and blacks. As a white widower, Elizabeth Curren expounds on the rising tide of militancy among black youths in her letters. To overcome racism and vindictive stereotyping, black youths try to be a generation whose hearts have swung to press because of the state abuse. The study reveals that the title Age of Iron captures the embodiment of the contemporary socio-political setting in South Africa showing the final breaths of the dishonorable arrangement of apartheid regime. It could be elicited that the title introduces differently to the iron will of the dark youngster progressives, Ms. Curren daughter's firm resolve not to come back to South Africa till the National Party rules is over, her persistence both in not persuading her daughter to return and her political will and to the iron laws of child rearing material to both Florence and herself. In other words, it refers to the era of political unrest and anarchy in South Africa set apart by a brutal protection of the dark youth in light of the apartheid regime.

On the whole, being one of Africa's most talented contemporary novelists, Coetzee examines the total influence of oppression and racism by addressing the contradictions and brutalities connected with the policy of apartheid in South Africans. Therefore, researchers are recommended to conduct studies on socio-political aspects of his novels especially his political viewpoints that spreads beyond social and geographic boundaries to accomplish universal significance. Coetzee's use of literary devices such as enigmatic symbolic settings, unreliable narrators and, most importantly, allegory need to be deeply investigated to reveal how they help him achieve his thoughts and viewpoints. Reading his novels, one can find that J.M. Coetzee personifies the whites' split personality in South Africa.

\section{References}

Ashcroft, B., Griffiths, G., \& Tiffin, H. (2013). Post-colonial studies: The key concepts: routledge. Attwell, D. (1992). Doubling the point: Essays and interviews: Harvard University Press.

Bhabha, H. K. (2003). The Ambivalence of Colonial Discourse. October The First.

Bhagavatidevi, C., Kalaria, A., \& Rachit, D. (2017). Reverberation of History of Apartheid in Age of Iron and Disgrace. The Criterion: An International Journal In English, 8(1), 777-783.

Coetzee, J. M. (2019). Age of iron: Text Publishing.

Fanon, F. (2001). The Wretched of the Earth (Preface by JP Sartre (trans.) Constance Farrington). In: Penguin Books, Harmondsworth.

Head, D. (2009). The Cambridge Introduction to JM Coetzee: Cambridge University Press.

James, D. (2020). Styles: Dusklands, Age of Iron, Disgrace, The Schooldays of Jesus. The Cambridge Companion to JM Coetzee, 64.

Khalaf, F. H. M. (2019). A Journey of Salvation and Redemption through Displacement: A Psychoanalytic Reading of JM Coetzee's Age of Iron. Middle East Journal, 4(51), 37-62.

Lucia, D. (2020). " Quid Est Classicum?" The Classics and South Africa in JM Coetzee's Age of Iron.

Myklatun, A. (2018). The Ethics of Proximity in Literature: An Ethical Reading of Immediacy in JM Coetzee's Age of Iron and Foe. UiT Norges arktiske universitet,

Racine, L. (2011). The Impact of Race, Gender, and Class in Postcolonial Feminist Fieldwork: A Retrospective Critique of Methodological Dilemmas. Aporia, 3(1).

Said, E. W. (2012). Culture and imperialism: Vintage. 
DOI: https://doi.org/10.47405/mjssh.v5i10.524

Salih, S. J., \& Janoory, L. (2019). On Feminism and Identity in JM Coetzee Literature: A Critical Analysis from Post-Colonial Perspective. Malaysian Journal of Social Sciences and Humanities (MJSSH), 4(3), 44-57.

Sanders, M. (2006). Undesirable Publications: JM Coetzee on Censorship and Apartheid. Law \& Literature, 18(1), 101-114.

Senghor, L. ( 1965). Prose and poetry (Senghor Ed.): Oxford University Press.

Spivak, G. C. (2016). Can the subaltern speak? (G. Riach Ed.): Macat International Limited ? London.

Wade, M. (2016). White on black in South Africa: a study of English-language inscriptions of skin colour: Springer.

Walder, D. (1990). Literature in the modern world: critical essays and documents: Oxford University Press in association with Open University. 